\title{
Does landscape context affect pollination- related functional diversity and richness of understory flowers in forest fragments of Atlantic Rainforest in southeastern Brazil?
}

Karoline Baptista de Lima ${ }^{1,2}$, Patrícia Alves Ferreira ${ }^{1,2}$, Milton Groppo ${ }^{1}$, Renato Goldenberg ${ }^{3}$, Emerson Ricardo Pansarin ${ }^{1}$, Roxana Cardoso Barreto ${ }^{4}$, Guilherme Peres Coelho ${ }^{5}$, Yago Barros-Souza ${ }^{6}$ and Danilo Boscolo ${ }^{1,2^{*}}$ (D)

\begin{abstract}
Background: How landscape modifications affect functional diversity of floral characteristics pertinent to pollinators is poorly known. Flowers possess functional traits that sometimes coevolved with pollinators, crucial for the maintenance of both pollinator and plant communities. We evaluated how richness and functional diversity of available understory flowers respond to forest cover and landscape heterogeneity in a multiscale analysis. Plants in bloom were sampled from 25 landscapes in the understory of Atlantic Forest fragments in Brazil. Species were classified into functional groups regarding flower characteristics relevant to pollination. Landscape heterogeneity and forest cover were measured in buffers ranging from 200 to $2000 \mathrm{~m}$ from sampling units and their correlation with plant richness and functional diversity was assessed using generalized linear models and further model selection through Akaike's second-order information criterion.

Results: Plants' richness and functional diversity were affected negatively by forest cover. The former responded to forest cover at a regional scale while the latter responded at a local scale. Higher landscape heterogeneity increased richness and functional diversity.

Conclusions: Our results showed that forest cover and landscape heterogeneity are important to support biodiversity related to pollination, mostly due to the availability of diversified resources and nesting sites associated to different land-uses for pollinators and flowering plant communities. These findings should highlight, along with forest cover, landscape heterogeneity as an environmental management priority in rural tropical areas for mitigating the loss of plant biodiversity and enhancing ecosystem functioning.
\end{abstract}

Keywords: Functional diversity, Pollination, Landscape heterogeneity, Forest cover, Understory plant community

\footnotetext{
* Correspondence: danilo.boscolo@usp.br

'Biology Department, Faculty of Philosophy, Sciences and Letters, University

of São Paulo, Ribeirão Preto, SP 14040-901, Brazil

${ }^{2}$ National Institute of Science and Technology in Interdisciplinary and

Transdisciplinary Studies in Ecology and Evolution (IN-TREE), Salvador, Brazil

Full list of author information is available at the end of the article
}

\section{Springer Open}

(c) The Author(s). 2020 Open Access This article is licensed under a Creative Commons Attribution 4.0 International License, which permits use, sharing, adaptation, distribution and reproduction in any medium or format, as long as you give appropriate credit to the original author(s) and the source, provide a link to the Creative Commons licence, and indicate if changes were made. The images or other third party material in this article are included in the article's Creative Commons licence, unless indicated otherwise in a credit line to the material. If material is not included in the article's Creative Commons licence and your intended use is not permitted by statutory regulation or exceeds the permitted use, you will need to obtain permission directly from the copyright holder. To view a copy of this licence, visit http://creativecommons.org/licenses/by/4.0/. 


\section{Background}

Ecosystem changes driven by biodiversity loss are comparable to other global changes, such as global warming, due to the magnitude in which they affect ecosystem processes (Hooper et al. 2012). The loss of biodiversity can occur at population and community levels, and also as a result of functional diversity loss, causing negative consequences in the relationships of species and consequently to ecological systems (Cardinale et al. 2012). Despite the fact that most studies concerned about biodiversity loss quantify it using species richness, there is a growing consensus that functional diversity, or the value, variance, and relative abundance of species' functional traits (Tilman 2001) may be more determining for ecosystem functioning than the number of species alone (Díaz and Cabido 2001; Cadotte et al. 2011). Different species functional traits result in a complementary and redundant effect of niche occupation (Díaz and Cabido 2001). Therefore, if the functional traits of the remaining species are unique, the dynamics of ecosystem processes are more subjected to species and ecosystem function losses (Fahrig 2001; Fischer and Lindenmayer 2007; Cadotte et al. 2011).

Today, the major driving force that results in biodiversity loss is the expansion of human activities (Lambin et al. 2001; Fahrig 2003; Fischer and Lindenmayer 2007), causing the loss and degradation of native environments with pervasive effects on habitat availability. Habitat loss results in resource limitation and the consequent rise of competition, leading to both smaller population sizes and higher local extinction probabilities (Fischer and Lindenmayer 2007). Landscape heterogeneity changes may also have important consequences over biodiversity loss, but those consequences are still poorly understood (Fahrig et al. 2011; Boscolo et al. 2016). Some studies conducted in agricultural landscapes point to positive effects of environmental heterogeneity over the diversity of many groups of organisms, such as birds, mammals, arthropods, and angiosperms, regardless of the scale (Benton et al. 2003; Holzschuh et al. 2010; Kennedy et al. 2013; Moreira et al. 2015; Boscolo et al. 2017; Takata 2017; Nery et al. 2018). These effects arise mostly due to species different requirements during their life cycle, which can be provided through the availability of different environments that attend to their necessities (Benton et al. 2003; Fahrig et al. 2011).

Ultimately, human-made landscape changes are affecting many ecological relationships, among which pollination stands out as critically endangered (Ferreira et al. 2013; Moreira et al. 2015; Potts et al. 2016). The economic importance of pollination processes makes it a relevant issue, given that of the 115 major global food crops, 87 are dependent on animal pollination, totalizing $35 \%$ of the global production volume (Klein et al. 2007). Many studies already show decreases in native pollinator richness and abundance, flower visits, and fruit and seed production as consequences of landscape changes (Ricketts et al. 2008; Ferreira et al. 2013; Ferreira et al. 2015). Thus, pollination resilience, of either native vegetation or food crops, can be drastically affected, resulting not only in environmental losses but also in socioeconomic ones as well (Klein et al. 2007; Ricketts et al. 2008).

We also know that plant communities directly interact and interfere with the structure of pollinator communities, especially through the provision of diversified floral resources (Potts et al. 2003). Floral characteristics, such as color, shape, resource type, size, and anthesis period, may have adaptive value for their pollinating agents, determining the degree of generalization or specialization of a pollinator (Viana and Oliveira 2006; Rech et al. 2014), and consequently affecting biodiversity. The persistence of functioning ecosystems is therefore dependent on the maintenance of the functional diversity of both plants and pollinators within these interaction networks (Fontaine et al. 2006). Even though there is no consensus whether the decline of pollinator diversity precedes the decline of plant diversity or the other way around, current evidence shows that both interact, leading to biological impoverishment, possibly having major consequences at the ecosystem level (Biesmeijer et al. 2006; Fontaine et al. 2006). However, because plants are sessile organisms and many need a biotic vector for pollen transference, the pollinator deficits imposed by changing landscapes may lead forest flowering plant communities to functional diversity loss and homogenization. By focusing on tropical forest understory plant communities in their flowering stage, in this study, we aimed to comprehend how forest cover and landscape heterogeneity in different scales influence floral functional diversity and species richness as a probable result of changes in pollinator availability. For that, we asked the following questions: (i) How does forest cover influence richness and functional diversity of understory plants in bloom? (ii) How does landscape heterogeneity affect the richness and functional diversity of blooming plant communities? (iii) Which landscape scales can better explain these variations? As it was not our objective to do a thorough phytosociological study or plant survey per se, but to evaluate possible landscape effects on understory functional flower diversity coupled to pollination processes, we focused exclusively on plants that were in bloom and receiving visits of potential pollinators.

\section{Methods}

\section{Study site selection}

Plants were sampled in the region between the Cantareira and Mantiqueira Mountain Ranges (São Paulo, Brazil), in the rural lands limited to the west by the city of Itatiba $\left(23^{\circ} 01^{\prime} 00^{\prime \prime} \mathrm{S} 46^{\circ} 50^{\prime} 00^{\prime \prime} \mathrm{W}\right)$ and to the east by Igaratá $\left(23^{\circ} 12^{\prime} 0^{\prime \prime} \mathrm{S} 46^{\circ} 09^{\prime} 00^{\prime \prime} \mathrm{W}\right)$, a place also known as the Cantareira-Mantiqueira Corridor. Originally covered by 
continuous Atlantic Forest, this region presented a multitude of vegetation cover types of Dense Ombrophilous Montane Forests, including hilltop, valley, and riparian forests (Veloso et al. 1991). The relevance of this area is due to its recent degradation history (less than 200 years, with greater intensity in the last century) and consequent variation in forest cover and land-use heterogeneity in different locations, as well as being considered an area with biodiversity conservation priority (Silva 2007). Nowadays, it is covered by a mosaic of second-growth Atlantic Forest patches (most up to 60 years old) in different recovery stages, pastures, small-sized fruit and vegetable crops, and urban development areas. Monthly rainfall during the sampling period varied from 6 to $454 \mathrm{~mm}$ (INMET 2019) including areas with dry winters and warm or cold summers (Cwb and Cwc) according to the Köppen-Geiger classification (Peel et al. 2007).

The studied region was mapped by the Spatial Ecology and Conservation Laboratory at the São Paulo State University (LEEC, UNESP - Rio Claro, São Paulo) through manual and supervised classifications using satellite and aerial images with $1 \mathrm{~m}$ of resolution (images came from the following sources: Esri, DigitalGlobe, GeoEye, Earthstar Geographics, CNES/Airbus DS, USDA, USGS, AEX, Getmapping, Aerogrid, IGN, IGP, swisstopo, and/or GIS User community). Land cover types were classified into 18 classes: water, initial forest, intermediate forest, advanced forest, initial pioneer forest, scrubland, annual agriculture, perennial agriculture, silviculture, bare soil, unmanaged pasture, degraded area, floodplain, floodplain with herbaceous shrub vegetation, floodplain with initial forest vegetation, rural village/condos with low density constructions, urban areas, and roads and highways. When wide enough to be correctly detected in images, road areas were calculated as polygons of that specific class in the landscape maps. After classification, these maps were groundtruthed and corrected until at least $90 \%$ of the region was correctly classified. These 18 land cover types were then reclassified into 13 classes by grouping land cover types with similar vegetational structure (Table 1) before calculating forest cover and landscape heterogeneity.

From the reclassified map and subsequent field verifications, we selected 25 sampling units inside Atlantic Forest fragments (Fig. 1). The selected sampling units intentionally formed a gradient of forest cover within a 1$\mathrm{km}$ radius that ranged from 12 to $96 \%$ (calculated from the final map), so that we could test the maximum possible variation in landscape forest availability. Correlation between surrounding forest cover and landscape heterogeneity was intentionally kept to a minimum so both factors could be concomitantly tested (Additional File 1). We considered initial forest, intermediate forest, and advanced forest all together to calculate landscape forest cover. The Shannon Diversity Index (Magurran 1988) is based on

Table 1 Land cover reclassification according to similarities of environmental structure

\begin{tabular}{|c|c|c|}
\hline Classes & Reclassification & Class description \\
\hline Water & A & Water bodies, lakes, and artificial reservoirs \\
\hline Initial forest & B & Forest in initial stage of regeneration, lacking canopy \\
\hline Intermediate forest & C & Intermediate forest with canopy varying from open to closed \\
\hline Advanced forest & $\mathrm{D}$ & Forest in climax stage with closed canopy \\
\hline Initial pioneer forest & E & $\begin{array}{l}\text { Forest in initial stage of ecological succession with sparse trees and lacking } \\
\text { canopy }\end{array}$ \\
\hline Scrubland & & Pasture with woody stratum, presence of herbaceous and shrub species \\
\hline Unmanaged pasture & $\mathrm{F}$ & $\begin{array}{l}\text { Pasture with presence of herbaceous and shrub species lacking agricultural } \\
\text { activity }\end{array}$ \\
\hline Annual agriculture & G & Short cycle agriculture with herbaceous species (ex. corn and beans) \\
\hline Perennial agriculture & & Long cycle agriculture with shrub species (ex. coffee and orange) \\
\hline Silviculture & $\mathrm{H}$ & Eucalyptus plantation \\
\hline Bare soil & । & Soil lacking vegetation, does not include areas for plantation \\
\hline Degraded area & & Degraded areas with bare soil and poor in nutrients (ex. mining areas) \\
\hline Floodplain & J & Waterfront areas that become flooded, with or without vegetation \\
\hline \multicolumn{3}{|c|}{ Floodplain with herbaceous shrub vegetation } \\
\hline \multicolumn{3}{|l|}{ Floodplain with initial forest vegetation } \\
\hline $\begin{array}{l}\text { Rural village/condos with low density } \\
\text { constructions }\end{array}$ & K & Areas with sparse dwellings with vegetation \\
\hline Urban areas & $\mathrm{L}$ & Urban areas lacking vegetation \\
\hline Roads and highways & M & Paved areas \\
\hline
\end{tabular}




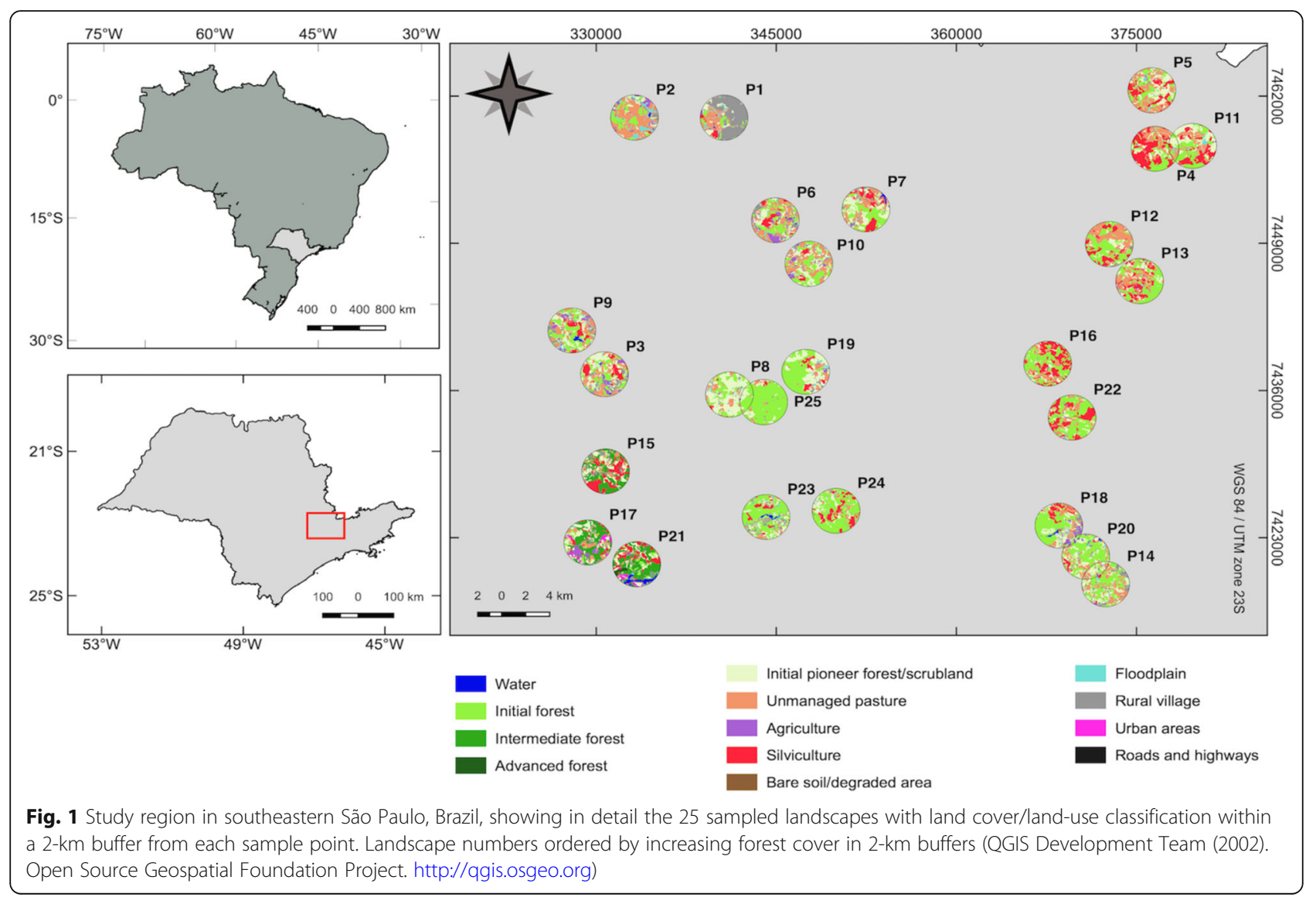

information theory and was used to calculate landscape heterogeneity, considering the amount and proportion of each reclassified land cover type in each landscape. This index can be equal to or larger than 0 , with no fixed limit, with its value rising with a higher richness of land cover types and/or with a more equitable area distribution among them. We chose to use this index because it is more sensitive to rare patch types than other landscape diversity indices (McGarigal et al. 2012), what could be decisive to explain variations in the studied system. All landscape metrics were calculated using Fragstats v4.3 (McGarigal et al. 2012) and a raster layer of the classified study area with $1 \mathrm{~m}$ raster resolution.

\section{Sampling and plant identification}

We installed hexagonal parcels with $25 \mathrm{~m}$ sides and area of 0.16 ha at the center of each $1 \mathrm{~km}$ radius landscape, in the interior of forest fragments, where we sampled plants in their flowering stage. Parcels were installed at least 50 $\mathrm{m}$ from forest interface with other land cover types to reduce edge effects. Plants that were in bloom within a height of up to $2 \mathrm{~m}$ were sampled and georeferenced, and their flowers were characterized for their color, diameter, and depth. At least a branch of all plants was herborized and identified up to the most specific taxonomic level possible by specialists, and their vouchers deposited in the Biology Department Herbarium of the University of São Paulo (SPFR) and the Botanic Department Herbarium of the Paraná Federal University (UPCB; Additional Files 2 and 3). Sampling was performed from December to March in 2015-2016 and in 2016-2017, periods when there was the highest possibility of finding plants in their flowering stage (Morellato LPC, personal communication). We divided the sampling periods into 3 phases of 5 to 7 days in the summers of 2015-2016 and 2016-2017, repeating sampling in each hexagonal parcel in each phase. Therefore, each sampling unit was sampled 3 times.

\section{Flower functional traits}

Sampled plants were classified according to their floral functional characteristics and their variation among sample points tested against the surrounding landscape structure. We selected floral functional traits which we considered the most relevant for flower-visitor interactions. In most cases, these interactions are established based on a resource that the flower makes available to the visitors and that can play a trophic, reproductive, or nest building role (Rech et al. 2014). However, for the interaction to occur, flowers usually present attractive 
cues directed to certain types of pollinators, such as size and color, that selectively signal visitors to the probable presence of resources (Rech et al. 2014), even if only as mimicry. We measured the diameter of the flower unit, which could be the individual flower or inflorescence that looks like a single flower (Faegri and Van der Pijl 1979), as an indicator of flower size. On the other hand, morphological characteristics of the flower, such as depth and blossom type, can act on the exclusion of visitors with subminimum adaptations to fulfill their pollination roles, allowing only better-adapted visitors access to their resources (Van der Pijl 1960; Van der Pijl 1961). Just as flower morphology can act upon the specialization of their pollinators, the way pollen is presented by a flower can also have a similar role. Even though most angiosperms possess anthers with longitudinal dehiscence (Simpson 2010) whose pollen becomes more accessible, many species present distinct strategies for limiting pollen access to non-adapted pollination vectors (Castellanos et al. 2005). These strategies vary from anther location that can be exposed or internalized inside the corolla, secondary pollen presentation, vector activated trigger mechanisms, and attractive antherodes to very restrictive adaptive mechanisms such as anthers with poricidal dehiscence and pollen aggregation into structures called pollinia (Leins and Erbar 1990; Faden 1992; Aluri and Reddi 1995; Johnson and Edwards 2000; Castellanos et al. 2005; De Luca and Vallejo-Marín 2013). Therefore, the functional traits chosen for this study were floral resource, flower color, flower diameter, flower depth, blossom type, and pollen presentation strategy.

Collected plants were then classified into functional groups (Table 2) within which all plants shared similar functional traits (Tilman 2001). We used floral biology, pollination, and taxonomic bibliography to obtain data on species' floral resources and pollen presentation strategy. For species with no specific bibliography, data was generalized for its next highest botanical level according to Simpson (2010) and Wanderley et al. (2001). We used our field notes on flower color, flower diameter, and flower depth to classify plants into their functional groups, calculating for diameter and depth a mean of all the values of individuals observed in field campaigns belonging to the same species. Photographs and herborized material of the plants in bloom were used to classify species according to their blossom type. The sampled plant species classification into their respective functional groups for the six functional traits can be verified in Additional File 3.

To measure functional diversity for each floral trait in each sample unit, we adopted the Shannon Diversity Index $\left(H^{\prime}\right)$, for which we used the number of functional groups at a given sample unit and the number of species classified in each functional group in the place of species richness and species abundance, respectively (Additional
File 4). We opted for using this index due to its advantage of increasing the weight of rare species, in this case, rare functional groups, by multiplying the proportion "species per functional group/total functional groups richness" by the natural logarithm (Magurran 1998; Melo 2008). We also choose this index for its easy understanding and its well-spread uses in ecological studies that would add comparability to other studies. With this, the incidence of new functional groups with low representation would have a higher weight in the final index, taking into account some rare functional groups with low representation that may be extremely relevant for the most specialized pollinators.

\section{Data analysis}

In order to select the most appropriate scale of effect of the tested landscape factors, we started our analysis with the selection of the landscape scales that had the strongest effects over the functional diversity indices and species richness. To do this, we calculated landscape forest cover and heterogeneity in the following scales: $200,300,400,500,750$, $1000,1250,1500,1750,1850$, and $2000 \mathrm{~m}$ of radius around each sampling unit (Additional Files 5 and 6). We employed the commands "hist" and "plot" from the "graphics" package of the R Studio program (R Core Team 2013) on linear regressions to observe, through histograms, residual $\times$ adjusted and normal Q-Q plots, if the models satisfied linear regression assumptions. Since not a single simple linear model's residuals attended to the assumptions of linear regressions for normal distribution, linear relation, and homoscedasticity, plant functional diversity was then compared to landscape structure at varying scales using generalized linear models (GLMs). To adjust data on richness and functional diversity indices of each functional trait into the correct distribution family for the GLMs, we used the Shapiro-Wilk normality test and the Cullen and Frey Graph (Delignette-Muller and Dutang 2015) with bootstrap procedure (1000 repetitions) through the "descdist" function from the "fitdistrplus" package of the R Studio program (R Core Team 2013). Based on these analyses, we adopted a Gaussian distribution with "identity" link function to generate GLMs from data of the following functional traits: "flower color", "floral diameter", "floral depth", "blossom type", and "pollen presentation". For "floral resource" and "species richness", we utilized a Gaussian distribution with link function "log" and Poisson distribution with link function "log", respectively.

We generated GLMs of each response variable, species richness, and functional diversity of the six flower traits, at each landscape scale for both explanatory variables, forest cover, and landscape heterogeneity, separately, using the "glmulti" function from the "glmulti" package of the $\mathrm{R}$ Studio program (R Core Team 2013). The "glmulti" function makes it possible to generate all possible model combinations, taking into account the explanatory variables 
Table 2 Pollination-related functional traits and their respective functional groups

\begin{tabular}{|c|c|c|c|}
\hline Functional trait & Functional group & Description & Reference \\
\hline \multirow[t]{5}{*}{ Floral diameter } & Inconspicuous & $\leq 4 \mathrm{~mm}$ & \multirow[t]{5}{*}{ Machado and Lopes 2004} \\
\hline & Small & $>4 \leq 10 \mathrm{~mm}$ & \\
\hline & Medium & $>10 \leq 20 \mathrm{~mm}$ & \\
\hline & Big & $>20 \leq 30 \mathrm{~mm}$ & \\
\hline & Very big & $>30 \mathrm{~mm}$ & \\
\hline \multirow[t]{5}{*}{ Floral depth } & Inconspicuous & $\leq 4 \mathrm{~mm}$ & \multirow[t]{5}{*}{ Machado and Lopes 2004} \\
\hline & Small & $>4 \leq 10 \mathrm{~mm}$ & \\
\hline & Medium & $>10 \leq 20 \mathrm{~mm}$ & \\
\hline & Big & $>20 \leq 30 \mathrm{~mm}$ & \\
\hline & Very big & $>30 \mathrm{~mm}$ & \\
\hline \multirow[t]{6}{*}{ Floral resource } & Pollen & & \multirow{6}{*}{$\begin{array}{l}\text { Girão et al. 2007; } \\
\text { Rech et al. } 2014\end{array}$} \\
\hline & Nectar & & \\
\hline & Pollen + nectar & & \\
\hline & Oil & & \\
\hline & No resource & & \\
\hline & Other diverse resources & $\begin{array}{l}\text { May include a combination of the above and other types of } \\
\text { resources }\end{array}$ & \\
\hline \multirow[t]{7}{*}{ Flower color } & White & & \multirow[t]{7}{*}{ Machado and Lopes 2004} \\
\hline & Red & & \\
\hline & $\begin{array}{l}\text { Green (including beige and } \\
\text { creme) }\end{array}$ & & \\
\hline & Yellow & & \\
\hline & Orange & & \\
\hline & Lilac/violet (including blue) & & \\
\hline & Pink & & \\
\hline \multirow[t]{7}{*}{ Blossom type } & Inconspicuous & $\leq 4 \mathrm{~mm}$ and no attractive structures & \multirow{7}{*}{$\begin{array}{l}\text { Faegri and Van der Pijl } \\
1979\end{array}$} \\
\hline & Plate/dish & & \\
\hline & Funnel & & \\
\hline & Brush & & \\
\hline & Gullet & & \\
\hline & Flag & & \\
\hline & Tube & & \\
\hline \multirow[t]{6}{*}{$\begin{array}{l}\text { Pollen presentation } \\
\text { strategy }\end{array}$} & Accessible & $\begin{array}{l}\text { Anther with longitudinal dehiscence and exposed outside the flower } \\
\text { perianth }\end{array}$ & \multirow[t]{2}{*}{ Simpson 2010} \\
\hline & Internal & $\begin{array}{l}\text { Anther with longitudinal dehiscence and inside the flower perianth, } \\
\text { making access more difficult }\end{array}$ & \\
\hline & $\begin{array}{l}\text { Accessible secondary } \\
\text { presentation }\end{array}$ & $\begin{array}{l}\text { Secondary pollen presentation with pollen exposed outside flower } \\
\text { perianth }\end{array}$ & \multirow[t]{2}{*}{$\begin{array}{l}\text { Leins and Erbar 1990; } \\
\text { De Araújo et al. } 2014\end{array}$} \\
\hline & $\begin{array}{l}\text { Internal secondary } \\
\text { presentation }\end{array}$ & $\begin{array}{l}\text { Secondary pollen presentation with pollen exposed inside flower } \\
\text { perianth }\end{array}$ & \\
\hline & Poricidal & $\begin{array}{l}\text { Type of anther dehiscence which access is limited to bees that can } \\
\text { withdraw pollen through its vibration }\end{array}$ & $\begin{array}{l}\text { De Luca and Vallejo-Marín } \\
2013\end{array}$ \\
\hline & Pollinia & $\begin{array}{l}\text { Pollen packed into hard structure, making it unavailable as a resource } \\
\text { and its access extremely specific to effective pollinators }\end{array}$ & $\begin{array}{l}\text { Johnson and Edwards } \\
2000\end{array}$ \\
\hline
\end{tabular}


Table 2 Pollination-related functional traits and their respective functional groups (Continued)

\begin{tabular}{llll}
\hline Functional trait & Functional group & Description & Reference \\
\hline Active & $\begin{array}{l}\text { Mechanism that needs to be triggered by legitimate pollinators to } \\
\text { expose pollen }\end{array}$ & Aluri and Reddi 1995 \\
& $\begin{array}{l}\text { Attractive antherodes } \\
\text { viable pollen, while true anthers are inconspicuous and } \\
\text { loaded with viable pollen for effective pollinators }\end{array}$ & Faden 1992 \\
& $\begin{array}{l}\text { Species that present flowers with style at different heights } \\
\text { in relation to anthers }\end{array}$ & Lopes and Buzato 2005 \\
\end{tabular}

specified in the function, adjusting these models to the GLMs, and returning us the best models based on the Akaike's second-order information criterion (AICc; Calcagno and Mazancourt 2010, Burnham and Anderson 2002). To choose the scales that best adjust to the response variables, we first selected the 3 most important forest cover and landscape heterogeneity scales, to decrease the number of parameters in our subsequent model selection analysis. These terms were computed as the sum of the relative weights of evidence (wi) of every model in which that term appears (Calcagno and Mazancourt 2010).

After determining the best scale of effect for each landscape factor, we selected the best models for each functional trait and species richness, to identify the effects of landscape metrics on flower metrics, using the same method as before, with the "glmulti" function from the "glmulti" package of the R Studio package (R Core Team 2013). We used the three best scales of each explanatory variable as parameters, as well as a null model, with one intercept, and determining the maximum number of parameters per model equal to two. We maintained AICc as our information criterion, as well as the statistical distribution of our response variables. To select the best models, we considered the AICc value of each model, the model's weights of evidence (wi), the models contemplated in the interval $\triangle \mathrm{AICc}<2$, and the correlation between the scales that appear in the same model. We did not include in the models variables that were correlated above \pm 0.75 . We considered that the best models were not plausibly better than the null hypothesis if the null model was present in the interval of $\triangle \mathrm{AICc}<2$ (Burnham and Anderson 2002).

\section{Results}

In all sampled landscapes, we recorded 125 species of plants in bloom belonging to at least 33 botanical families (Additional File 2). The families with the highest species richness were Rubiaceae (20 species), Melastomataceae (13 species), Poaceae (12 species), and Orchidaceae (9 species). Most of these plants depend on animal pollinators for reproduction. Among these plants, there were only two in Melastomataceae family with evidence of apomixis (Leandra melastomoides Raddi and Miconia latecrenata (DC.) Naudin; Goldenberg and Varassin 2001). However, only few species have been studied for apomixis, and there is probably a subsampling of this condition among angiosperms; for that reason, we decided to keep these species in our analyses, even knowing that they may not need to or attract pollinators. We kept them as they were present in the communities and may function for pollinators' maintenance by offering complimentary flower resources.

\section{Scale selection}

We have identified the effects of forest cover at local scales $(\leq 500 \mathrm{~m})$ for "flower color", "blossom type" and "pollen presentation", while for "floral resource", "floral diameter", "floral depth" and "species richness", the scales with the highest evidence of effect varied from local to regional scales $(200-2000 \mathrm{~m})$. For landscape heterogeneity, we have identified evidence of its effects in "floral resource", "flower color", "floral depth" and "species richness" for local and regional scales, while for "floral diameter", "blossom type" and "pollen presentation", the evidence was from effects for the regional scales $(1750-2000 \mathrm{~m})$. As explained in the "Methods" section, we used these three scales with the highest weights of evidence for each explanatory variable for the model selection of each response variable (Table 3).

\section{Model selection}

The best ranked model showed that the functional trait floral resource (Additional File 7) responded at local scales $(<500 \mathrm{~m})$ to forest cover and land-use heterogeneity, at $400 \mathrm{~m}$ and $200 \mathrm{~m}$, respectively (Table 3). The functional diversity of floral resources decreased with the increase of forest cover in a 400-m buffer (slope = $0.01 ; p=0.01$; Fig. 2a) and with increasing land-use heterogeneity in a $200-\mathrm{m}$ buffer (Fig. 2a). Explanatory variables were correlated in these scales (correlation = 0.73; Additional File 1), indicating that the effects of forest cover and land-use heterogeneity were influencing floral resources in an additive way. The second best model showed that land-use heterogeneity in a regional scale $(2000 \mathrm{~m})$ had a positive effect on resource functional diversity, indicating landscape structure effects in various scales and which are probably related to different processes happening in the system. The third best model also showed the influence of forest cover on the floral 
Table 3 Best ranked models and null model for floral resource functional diversity and species richness

\begin{tabular}{|c|c|c|c|c|}
\hline Model ranking & Model & AICc & $\triangle \mathrm{AICC}$ & wi \\
\hline \multicolumn{5}{|c|}{ Floral resource functional diversity } \\
\hline 1 & $\sim$ Forest_cover_400m + heterogeneity_200m & 15.52 & 0 & 0.22 \\
\hline 2 & Heterogeneity_2000m & 16.91 & 1.39 & 0.11 \\
\hline 3 & $\sim$ Forest_cover_400m + forest_cover_200m & 17.10 & 1.58 & 0.10 \\
\hline 4 & $\sim 1$ & 17.58 & 2.06 & 0.08 \\
\hline \multicolumn{5}{|c|}{ Species richness of plants in bloom } \\
\hline 1 & Forest_cover_2000m & 147.11 & 0 & 0.19 \\
\hline 2 & Forest_cover_2000m + heterogeneity_300m & 148.42 & 1.31 & 0.10 \\
\hline 3 & Heterogeneity_200m + heterogeneity_300m & 148.64 & 1.53 & 0.09 \\
\hline 14 & $\sim 1$ & 151.55 & 4.44 & 0.02 \\
\hline
\end{tabular}

resource functional diversity in the local scales around $400 \mathrm{~m}$ and $200 \mathrm{~m}$. The first three models selected could be considered equally plausible as the $\triangle \mathrm{AICc}$ was lower than two. All three models were considerably different from the null model as its $\triangle \mathrm{AICc}$ was higher than two (Table 3).

Landscape factors also influenced species richness of understory flowering plants. The best ranked model showed that plant species richness responded negatively to forest cover at a regional scale of $2000 \mathrm{~m}$ (wi $=0.19$; Fig. 2b). The second and third ranked models showed a positive effect of land-use heterogeneity in the species richness at local scales $(w i=0.10)$. The first three models selected could be considered equally plausible as the $\triangle \mathrm{AICc}$ was lower than two and different from the null model with a $\triangle$ AICc higher than two (Table 3). These results showed consistent landscape effects over functional diversity and plant richness. Forest cover had a negative effect on floral resources diversity and species richness at local and regional scales, respectively. Landuse heterogeneity, however, had a negative effect on floral resources diversity at regional scales (possibly due to its relation to forest cover effects) and a positive effect on species richness at local scales. In the wider scales, the diversity of land-uses was positive for plant richness. We also verified a difference in scales in which these factors affect functional diversity and species richness. While forest cover acts upon resource functional a)

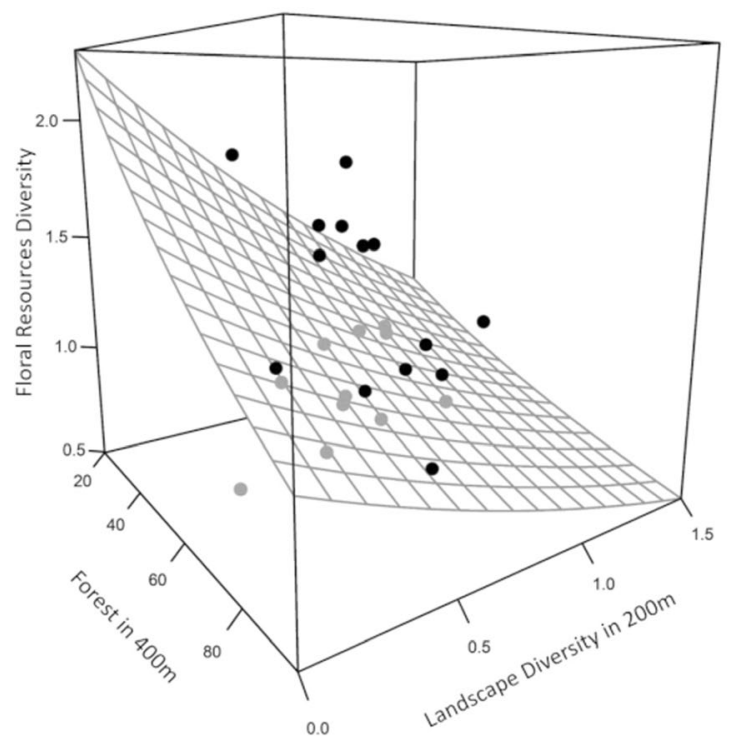

b)

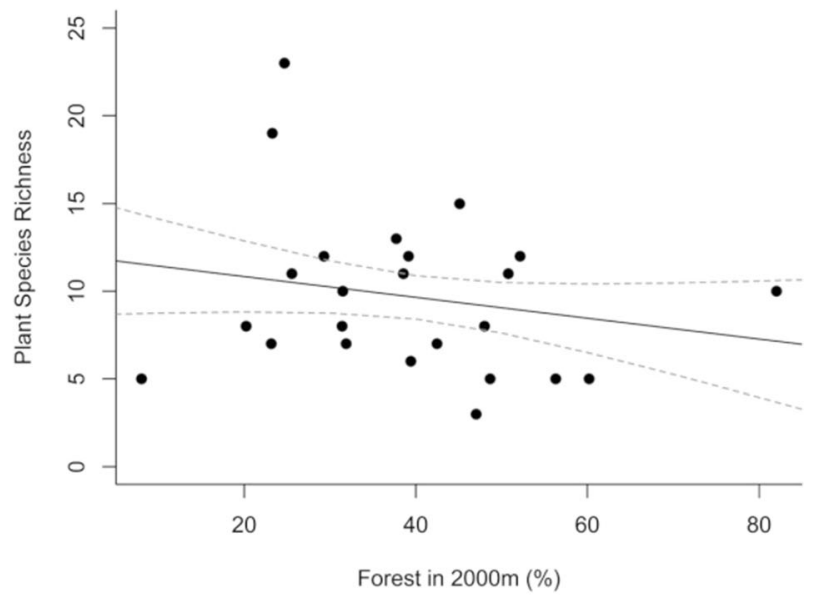

Fig. 2 a Effects of forest cover (\%) at a 400-m scale and landscape heterogeneity $\left(H^{\prime}\right)$ at a 200-m scale on floral resource functional diversity $\left(H^{\prime}\right)$; black dots represent values above the surface and gray dots below. b Effects of forest cover (\%) at a 2000-m scale on species richness. Black dots are the residuals, and lines are the predicted values based on generalized linear models. Dashed lines represent confidence intervals ( $R$ Core Team, 2013) 
diversity at a local scale, for species richness, this effect takes place at a regional scale. This divergence in scalar effects is also true for land-use heterogeneity, as its effect over resource functional diversity operates at a regional scale and at a local scale for species richness.

For all the tested models, only the ones that considered the response variables "floral resources" and "species richness" had results that were different from the null models and, therefore, had plausible effects of explanatory variables on response variables. The models that include floral diameter, floral depth, flower color, blossom type, and pollen presentation strategies were not influenced by the explanatory variables.

\section{Discussion}

Forest cover had a negative effect on the functional diversity and species richness of understory plants in bloom. This effect can be related to the structure of the forest inside the forest fragments with their particularities. As forest cover in a landscape gets higher, there are higher chances of forming larger clumps of continuous areas of forest, decreasing edge effects (Fahrig 2003), as well as light penetration in the understory due to a more developed canopy structure. With less light inside the forest, many understory plant species may have their blossom density reduced as a result of a lower intensity of photosynthetic processes and consequently less carbon allocation to reproductive structures (Kudo et al. 2008). Kawarasaki and Hori (2001) found that flowering patterns of understory plants in temperate deciduous forests were conditioned to forest canopy density over the seasons. They saw that there were more plants flowering when there was more light into the understory. Because our study area is characterized by ombrophilous forests, where there is no significant leaf loss from one season to another, light penetration variation in the understory may have a stronger relation with spatial factors (closeness to forest edges), as well as structure and maturity of canopy forest species, and not a seasonal cause like in deciduous forests.

In addition, functional diversity of blooming plants can be responding to forest cover at a local scale because of its association to the internal structure of the forest. Takata (2017) analyzed 39 landscapes in the same study region, comprehending the 25 landscapes of the present research, and found an inverse correlation between local canopy cover and richness of understory plants that were in bloom. During field campaigns, we also observed the drastic difference in the abundance of flowers and species composition in forest understories, with few flowering individuals in comparison to adjacent open areas and forest edge. Due to the strong relationship between functional diversity and species richness (Díaz and Cabido 2001), it is not unexpected that forests with denser canopies limiting blooming density of understory plants also affect functional diversity. The best explanation for this is that species that did not bloom due to less light penetration in the understory have very different functional traits than the ones that did bloom, resulting in a lower diversity of these pollination-related characteristics. The more shaded conditions of better structured oldgrowth forests with fewer edge habitats may, through time, favor the maintenance of populations only of species which need less light to bloom excluding other invasive and more generalist edge community plants and thus reducing functional diversity. This, however, leads to distinct communities along the deforestation gradient. In fact, what we found was that in landscapes with high forest cover, the understory was dominated by forest specialist plants, such as those from the Rubiaceae (Palicourea, Psychotria), Commelinaceae (Dichorisandra), Piperaceae (Piper, Peperomia), and Marantaceae (Ctenanthe, Stromanthe) families (Additional File 2). Conversely, landscapes with less overall forest cover and more edge environments had a higher prevalence of generalist species in the understory, including those common in disturbed and open environments, such as Borreria sp., Sida spp., Pavonia communis, Lantana camara, Stachytarpheta cayennensis, and many Asteraceae and Poaceae (Additional File 2). This indicates that the higher functional diversity found in less forested landscapes is a by-product of invasive open-area and edge-opportunist species, while with more surrounding forests the understory plant community is more specialized for closed environments, thus being less functionally diverse and at the same time more sensitive to forest loss and fragmentation. The studied landscapes are in a region of frequent threats to forest environments, which are commonly converted mainly into agricultural lands and low density suburban expansion areas. This region is in a socioeconomic and political context that has allowed several cycles of cutting and recovery of natural vegetation in the last $60-80$ years. These cycles include, for instance, the rotation of sugar cane, coffee, fruits, and vegetable production, and the expansion of country houses and leisure areas. These cycles were interspersed with periods of land abandonment due to variations in economic, social, political, or environmental pressures, when the natural vegetation had time to recover. So this constant rotation and the rapid and frequent change in land-use have had effects mainly on the edges and inner forest structure of small forest fragments.

Contrary to forest cover, land-use heterogeneity affected resource functional diversity and species richness positively (Benton et al. 2003; Fahrig et al. 2011). Nonetheless, we observed that the fit of land-use heterogeneity models was inferior to that of forest cover models, considering the model rank in which land-use 
heterogeneity was the explanatory variable (Table 3 ). This could be explained by the fact that forest structure is acting over blooming understory plant species directly, through denser canopies limiting light penetration and consequently blooming density (Takata 2017), while landscape heterogeneity directly modifies pollinator communities through a more or less diversified feeding and nesting resources' availability, consequently affecting plant communities in an indirect way (Boscolo et al. 2017; Moreira et al. 2018; Nery et al. 2018). Nery et al. (2018) observed a positive effect of land-use heterogeneity, on a regional scale, over richness and diversity of bees sampled in the interior of these same forest fragments. In addition, they also reported that while forest cover had a negative impact on the diversity of bees foraging in the interior of these forest fragments, it had a positive impact over richness, diversity, and abundance of bees foraging in open areas adjacent to forest fragments. In other words, the forest may be acting as nesting sources for these pollinators (Takata 2017), while adjacent open areas act as complementary habitat (Dunning et al. 1992; Nery et al. 2018) offering food resources. This can also explain why land-use heterogeneity affected resource functional diversity at a regional scale, articulating with foraging ranges (Crouzeilles et al. 2010) and the spatial distribution of these animals. Land-use heterogeneity may thus be the key in maintaining understory plant biodiversity through its role in sustaining pollinator communities, fundamental for completing these plants' reproductive cycle.

Plants and animal pollinators have different responses to landscape changes, mostly due to their differences of individual longevity. As plants stay much longer in the landscapes, they respond to structural landscape changes more slowly than animals. For instance, Metzger et al. (2009) analyzed the time-lag of trees, small mammals, frogs, and birds in response to landscape modifications in distinct temporal scales and observed that plants correspond to the groups that better responded to past landscape configurations. Therefore, land-use heterogeneity may have more current intense effects on pollinator communities (see Nery et al. 2018) than on plant richness and functional diversity. Even though pollinator communities are changing in parallel to recent landscape modifications (Ferreira et al. 2015; Boscolo et al. 2017; Moreira et al. 2018; Nery et al. 2018), both these changes may not have had enough time to produce a perceivable variation inside these tropical forest understory plant communities. Nevertheless, we should not wait until plants' biological and functional diversity is lost to take action to protect them. Conservation and restoration programs must be planned ahead and implemented in these important and fragile landscapes to guarantee the long-term preservation of these processes.

\section{Conclusions}

Forest cover and land-use heterogeneity are relevant for the maintenance of understory plant richness and functional diversity in tropical forest fragmented landscapes mostly due to its effects on biodiversity that directly impact the persistence of plant communities. Open-area and edge-opportunist plants may be the result of the negative effects of low forest cover and high edge effects on plants' functional diversity. This effect could be clearly perceived in the field, for in more fragmented landscapes we could find more ruderal generalist plants invading forest patches than forest specialist plants within these fragments. This study may help deriving public decisions on the conservation and restoration of these landscapes. Agricultural and land-use policies should direct efforts towards increasing the diversity of crops in rural lands interspersed with native forests of different sizes and shapes in order to guarantee a higher diversity of conditions capable of safeguarding a diversified functional pool of plants and their pollinators. The accomplishment of such landscape structuration shall come from the strengthening of science-based environmental policies aiming at effective natural land conservation in private properties, given their importance for plant and pollinator communities.

\section{Supplementary information}

Supplementary information accompanies this paper at https://doi.org/10. 1186/s13717-020-00261-6.

\section{Additional file 1 . \\ Additional file 2. \\ Additional file 3. \\ Additional file 4 . \\ Additional file 5 . \\ Additional file 6 . \\ Additional file 7 .}

\section{Abbreviations}

LEEC: Spatial Ecology and Conservation Laboratory; UNESP: São Paulo State University; Esri: Environmental Systems Research Institute; CNES: Centre National D'études Spatiales; Airbus DS: Airbus Defence and Space; USDA: United States Department of Agriculture; USGS: United States Geological Survey; AEX: Aerials Express; IGN: Institut Géographique National; IGP: Instituto Geográfico Português; GIS: Geographic Information System; SPFR: Biology Department Herbarium of the University of São Paulo; UPCB: Botanic Department Herbarium of the Paraná Federal University; H': Shannon Diversity Index; GLM: Generalized linear models; AICc: Akaike's second-order information criterion; $\triangle \mathrm{AICC}$ : Difference of AICc from the best model; wi: Akaike weight of evidence

\section{Acknowledgements}

We are grateful to the Landscape Ecology and Analysis Pack (LEAP, USP Ribeirão Preto, SP) for the team work during field sampling, to the Spatial Ecology and Conservation Laboratory (LEEC, UNESP - Rio Claro, SP) for land cover classification of our study region, to the farmers that allowed us to conduct our study on their lands, and to Rodrigo S. Rodrigues, Daniele Monteiro, Cíntia Kameyama, Fabrício S. Meyer, Guilherme M. Antar, Luís C. Bernacci, Maria Alves, Matheus Nogueira, Nádia Roque, Rafael Trevisan, and 
José R. Barosela who aided us with plant identifications. We also thank Luciano E. Lopes for the help with statistical analyses and model selection.

\section{Authors' contributions}

$\mathrm{KBDL}$ carried out the project, analyzed the data, and wrote the manuscript. PAF was a major contributor to the experimental design, plant sampling and writting. MG was a major contributor to the plant identification phase and plant deposits in the SPFR herbarium. RG identified the plants belonging to the family Melastomataceae and carried out plant deposits in the UPCB herbarium. ERP identified the plants belonging to the family Orchidaceae. RCB identified the plants belonging to the family Commelinaceae. GPC identified the plants belonging to the Campanulaceae family. YBS identified the plants belonging to the family Fabaceae. DB advised every stage of the project and made major contributions to the experimental design, data collection, and overall conception of the research project and writing of this manuscript. All authors read and approved the final manuscript.

\section{Funding}

Funding was provided by the Conselho Nacional de Desenvolvimento Científico e Tecnológico MCTI/CNPq/Universal process 449740/2014-5, Fundação de Amparo à Pesquisa do Estado de São Paulo (FAPESP) process 2013/50421-2 and 2018/04337-3.

\section{Availability of data and materials}

The datasets used and/or analyzed during the current study are available from the corresponding author on reasonable request. All data generated or analyzed during this study are included in this published article and its supplementary information files.

\section{Ethics approval and consent to participate}

Sampling of biological material was licensed by SISBIO 42525-4

\section{Consent for publication}

Not applicable

\section{Competing interests}

The authors declare that they have no competing interests.

\section{Author details}

${ }^{1}$ Biology Department, Faculty of Philosophy, Sciences and Letters, University of São Paulo, Ribeirão Preto, SP 14040-901, Brazil. ${ }^{2}$ National Institute of Science and Technology in Interdisciplinary and Transdisciplinary Studies in Ecology and Evolution (IN-TREE), Salvador, Brazil. ${ }^{3}$ Botany Department, Biological Science Sector, Paraná Federal University, Curitiba, PR 81531-970, Brazil. ${ }^{4}$ Botany Department, Biological Science Center, Pernambuco Federal University, Recife, PE 50670-420, Brazil. Institute of Bioscience, Rio Grande do Sul Federal University, Porto Alegre, RS 90040-060, Brazil. ${ }^{6}$ Botany Department, Federal University of São Carlos, São Carlos, SP 13565-905, Brazil.

Received: 28 April 2020 Accepted: 21 September 2020

Published online: 09 November 2020

\section{References}

Aluri RJ, Reddi CS (1995) Explosive pollen release and pollination in flowering plants. Proc Nat Acad Sci India B 61:323-332

Benton TG, Vickery JA, Wilson JD (2003) Farmland biodiversity: is habitat heterogeneity the key? Trend Ecol Evol 18:182-188. https://doi.org/10.1016/ s0169-5347(03)00011-9

Biesmeijer JC, Roberts SP, Reemer M, Ohlemüller R, Edwards M, Peeters T, Schaffers AP, Potts SG, Kleukers R, Thomas CD, Settele J (2006) Parallel declines in pollinators and insect-pollinated plants in Britain and the Netherlands. Science 313:351-354. https://doi.org/10.1126/science.1127863

Boscolo D, Ferreira PA, Lopes LE (2016) Da Matriz a Matiz-Em busca de uma abordagem funcional para a ecologia de paisagens. Filosofia e História da Biologia 11:157-187

Boscolo D, Tokumoto PM, Ferreira PA, Ribeiro JW, Dos Santos JS (2017) Positive responses of flower visiting bees to landscape heterogeneity depend on functional connectivity levels. Perspect Ecol Conserv 15:18-24. https://doi. org/10.1016/j.pecon.2017.03.002
Burnham KP, Anderson DR (eds) (2002) A practical information-theoretic approach: model selection and multimodel inference. Springer, New York. https://doi.org/10.1007/b97636

Cadotte MW, Carscadden K, Mirotchnick N (2011) Beyond species: functional diversity and the maintenance of ecological processes and services. J Appl Ecol 48:1079-1087. https://doi.org/10.1111/j.1365-2664.2011.02048.x

Calcagno V, De Mazancourt C (2010) glmulti: an R package for easy automated model selection with (generalized) linear models. J Stat Software 34:1-29. https://doi.org/10.18637/jss.v034.i12

Cardinale BJ, Duffy JE, Gonzalez A, Hooper DU, Perrings C, Venail P, Narwani A, Mace GM, Tilman D, Wardle DA, Kinzig AP (2012) Biodiversity loss and its impact on humanity. Nature 486:59-67. https://doi.org/10.1038/nature11148

Castellanos MC, Wilson P, Keller SJ, Wolfe AD, Thomson JD (2005) Anther evolution: pollen presentation strategies when pollinators differ. Am Nat 167: 288-296. https://doi.org/10.2307/3491268

Crouzeilles R, Lorini ML, Grelle CEV (2010) Deslocamento na matriz para espécies da Mata Atlântica e a dificuldade da construção de perfis ecológicos. Oecol Austr 14:872-900. https://doi.org/10.4257/oeco.2010.1404.06

de Araújo LDA, Quirino ZGM, Machado IC (2014) High specialisation in the pollination system of Mandevilla tenuifolia (J.C. Mikan) Woodson (Apocynaceae) drives the effectiveness of butterflies as pollinators. Plant Biol 16:947-955

De Luca PA, Vallejo-Marín M (2013) What's the 'buzz' about? The ecology and evolutionary significance of buzz-pollination. Curr Opin Plant Biol 16:429-435. https://doi.org/10.1016/j.pbi.2013.05.002

Delignette-Muller ML, Dutang C (2015) fitdistrplus: an R package for fitting distributions. J Stat Software 64:1-34. https://doi.org/10.18637/jss.v064.104

Diaz S, Cabido M (2001) Vive la différence: plant functional diversity matters to ecosystem processes. Trend Ecol Evol 16:646-655. https://doi.org/10.1016/ s0169-5347(01)02283-2

Dunning JB, Danielson BJ, Pulliam HR (1992) Ecological processes that affect populations in complex landscapes. Oikos 65:169-175. https://doi.org/10. 2307/3544901

Faden RB (1992) Floral attraction and floral hairs in the Commelinaceae. Ann Missouri Botan Garden 79:46-52. https://doi.org/10.2307/2399808

Faegri K, Van der Pijl L (eds) (1979) The principles of pollination ecology. Pergamon Press, Oxford

Fahrig $L$ (2001) How much habitat is enough? Biol Conserv 100:65-74. https:// doi.org/10.1016/s0006-3207(00)00208-1

Fahrig L (2003) Effects of habitat fragmentation on biodiversity. Ann Rev Ecol Evol Syst 34:487-515. https://doi.org/10.1146/annurev.ecolsys.34.011802.132419

Fahrig L, Baudry J, Brotons L, Burel FG, Crist TO, Fuller RJ, Sirami C, Siriwardena GM, Martin JL (2011) Functional landscape heterogeneity and animal biodiversity in agricultural landscapes. Ecol Lett 14:101-112. https://doi.org/ 10.1111/j.1461-0248.2010.01559.x

Ferreira PA, Boscolo D, Carvalheiro LG, Biesmeijer JC, Rocha PL, Viana BF (2015) Responses of bees to habitat loss in fragmented landscapes of Brazilian Atlantic Rainforest. Landscape Ecol 30:2067-2078. https://doi.org/10.1007/ s10980-015-0231-3

Ferreira PA, Boscolo D, Viana BF (2013) What do we know about the effects of landscape changes on plant-pollinator interaction networks? Ecol Indic 31: 35-40. https://doi.org/10.1016/j.ecolind.2012.07.025

Fischer J, Lindenmayer DB (2007) Landscape modification and habitat fragmentation: a synthesis. Glob Ecol Biogeogr 16:265-280. https://doi.org/ 10.1111/j.1466-8238.2007.00287.x

Fontaine C, Dajoz I, Meriquet J, Loreau M (2006) Functional diversity of plantpollinator interaction webs enhances the persistence of plant communities. PLoS Biol 4:e1. https://doi.org/10.1371/journal.pbio.0040001

Girão LC, Lopes AV, Tabarelli M, Bruna EM (2007) Changes in tree reproductive traits reduce functional diversity in a fragmented Atlantic forest landscape. PLoS One 2:e908. https://doi.org/10.1371/journal.pone.0000908

Goldenberg R, Varassin IG (2001) Breeding systems of Melastomataceae in Serra do Japi, Jundiaí, São Paulo, Brazil. Braz J Bot 24:283-288. https://doi.org/10. 1590/s0100-84042001000300006

Holzschuh A, Steffan-Dewenter I, Tscharntke T (2010) How do landscape composition and configuration, organic farming and fallow strips affect the diversity of bees, wasps and their parasitoids? J Anim Ecol 79:491-500. https://doi.org/10.1111/j.1365-2656.2009.01642.x

Hooper DU, Adair EC, Cardinale BJ, Byrnes JE, Hungate BA, Matulich KL, Gonzalez A, Duffy JE, Gamfeldt L, O'Connor MI (2012) A global synthesis reveals biodiversity loss as a major driver of ecosystem change. Nature 486:105-108. https://doi.org/10.1038/nature11118 
Johnson SD, Edwards TJ (2000) The structure and function of orchid pollinaria. Plant Syst Evol 222:243-269. https://doi.org/10.1007/bf00984105

Kawarasaki S, Hori Y (2001) Flowering phenology of understory herbaceous species in a cool temperate deciduous forest in Ogawa Forest Reserve, Central Japan. J Plant Res 114:19-23. https://doi.org/10.1007/pl00013964

Kennedy CM, Lonsdorf E, Neel MC, Williams NM, Ricketts TH, Winfree R, Bommarco R, Brittain C, Burley AL, Cariveau D, Carvalheiro LG (2013) A global quantitative synthesis of local and landscape effects on wild bee pollinators in agroecosystems. Ecol Lett 16:584-599. https://doi.org/10.1111/ele.12082

Klein AM, Vaissiere BE, Cane JH, Steffan-Dewenter I, Cunningham SA, Kremen C, Tscharntke T (2007) Importance of pollinators in changing landscapes for world crops. Proc Royal Soc London B Biol Sci 274:303-313. https://doi.org/ 10.1098/rspb.2006.3721

Kudo G, Ida TY, Tani T (2008) Linkages between phenology, pollination, photosynthesis, and reproduction in deciduous forest understory plants. Ecology 89:321-331. https://doi.org/10.1890/06-2131.1

Lambin EF, Turner BL, Geist HJ, Agbola SB, Angelsen A, Bruce JW, Coomes OT, Dirzo R, Fischer G, Folke C, George P (2001) The causes of land-use and landcover change: moving beyond the myths. Global Environ Change 11:261269. https://doi.org/10.1016/s0959-3780(01)00007-3

Leins P, Erbar C (1990) On the mechanisms of secondary pollen presentation in the Campanulales-Asterales-complex. Botanica Acta 103:87-92. https://doi. org/10.1111/j.1438-8677.1990.tb00131.x

Lopes LE, Buzato S (2005) Biologia reprodutiva de Psychotria suterella Muell. Arg. (Rubiaceae) e a abordagem de escalas ecológicas para a fenologia de floração e frutificação. Revista Brasileira de Botânica 28:785-795. https://doi. org/10.1590/s0100-84042005000400013

Machado IC, Lopes AV (2004) Floral traits and pollination systems in the Caatinga, a Brazilian tropical dry forest. Ann Bot 94:365-376. https://doi.org/10.1093/ aob/mch152

Magurran AE (1988) Ecological diversity and its measurement. Princeton, New Jersey. In: doi.org/10.1007/978-94-015-7358-0

Melo AS (2008) O que ganhamos 'confundindo' riqueza de espécies e equabilidade em um índice de diversidade? Biota Neotropica 8:21-27. https://doi.org/10.1590/s1676-06032008000300001

Metzger JP, Martensen AC, Dixo M, Bernacci LC, Ribeiro MC, Teixeira AMG, Pardini $R$ (2009) Time-lag in biological responses to landscape changes in a highly dynamic Atlantic forest region. Biol conserv 142:1166-1177. https://doi.org/ 10.1016/j.biocon.2009.01.033

Moreira EF, Boscolo D, Viana BF (2015) Spatial heterogeneity regulates plantpollinator networks across multiple landscape scales. PLoS One 10:e0123628. https://doi.org/10.1371/journal.pone.0123628

Moreira EF, Boscolo D, Viana BF (2018) Beyond good and evil: context-dependent effects of agriculture on pollinators' communities and its interactions. Oecol Aust 22:490-502. https://doi.org/10.4257/oeco.2018.2204.11

Nery LS, Takata JT, De Camargo BB, Chaves AM, Ferreira PA, Boscolo D (2018) Bee diversity responses to forest and open areas in heterogeneous Atlantic Forest. Sociobiology 65:686-695. https://doi.org/10.13102/sociobiology.v65i4.3472

Peel MC, Finlayson BL, McMahon TA (2007) Updated world map of the KöppenGeiger climate classification. Hydrol Earth System Sci Discuss 11:1633-1644. https://doi.org/10.5194/hess-11-1633-2007

Potts SG, Imperatriz-Fonseca VL, Ngo HT, Biesmeijer JC, Breeze TD, Dicks LV, Garibaldi LA, Hill R, Settele J, Vanbergen AJ, Aizen MA, Cunningham SA Eardley C, Freitas BM, Gallai N, Kevan PG, Kovács-Hostyánszki A, Kwapong PK, Li J, Li X, Martins DJ, Nates-Parra G, Pettis JS, Rader R, Viana BF (eds.). IPBES (2016): Summary for policymakers of the assessment report of the Intergovernmental Science-Policy Platform on Biodiversity and Ecosystem Services on pollinators, pollination and food production. Secretariat of the Intergovernmental Science-Policy Platform on Biodiversity and Ecosystem Services, Bonn, Germany. 36.

Potts SG, Vulliamy B, Dafni A, Ne'eman G, Willmer P (2003) Linking bees and flowers: how do floral communities structure pollinator communities? Ecology 84:2628-2642. https://doi.org/10.1890/02-0136

Rech AR, Agostini K, Oliveira PE, Machado IC (2014) Biologia da Polinização. Editora Projeto Cultural, Rio de Janeiro

Ricketts TH, Regetz J, Steffan-Dewenter I, Cunningham SA, Kremen C, Bogdanski A, Gemmill-Herren B, Greenleaf SS, Klein AM, Mayfield MM, Morandin LA (2008) Landscape effects on crop pollination services: are there general patterns? Ecol Lett 11:499-515. https://doi.org/10.1111/j.1461-0248.2008.01157.x

Simpson MG (2010) Plant systematics. Elsevier, Burlington
Takata JT (2017) Abelhas visitantes florais da Mata Atlântica: efeitos de fatores locais e de paisagem. Dissertation, Universidade de São Paulo

Tilman D (2001) Functional diversity. Encyclopedia Biodiversity 3:109-120. https://doi.org/10.1006/rwbd.1999.0154

Van der Pijl L (1960) Ecological aspects of flower evolution. I. Phyletic evolution. Evolution 14:403-416. https://doi.org/10.1111/j.1558-5646.1960.tb03108.x

Van der Pijl L (1961) Ecological aspects of flower evolution. II. Zoophilous flower classes. Evolution 15:44-59. https://doi.org/10.1111/j.1558-5646.1961.tb03128.x

Veloso HP, Filho ALRR, Lima JCA (1991) Classificação da Vegetação Brasileira, Adaptada a um Sistema Universal. Fundação Instituto Brasileiro de Geografia e Estatística, Rio de Janeiro

Viana BF, Oliveira FF (2006) Biologia e Ecologia da Polinização: Cursos de Campo. Fundo Brasileiro para a Biodiversidade, Rio de Janeiro

Wanderley MDGL, Shepherd GJ, Melhem TS (2001) Flora fanerogâmica do estado de São Paulo (Vols. 1-8). Editora Hucitec, São Paulo

\section{Publisher's Note}

Springer Nature remains neutral with regard to jurisdictional claims in published maps and institutional affiliations.

\section{Submit your manuscript to a SpringerOpen ${ }^{\circ}$ journal and benefit from:}

- Convenient online submission

- Rigorous peer review

- Open access: articles freely available online

High visibility within the field

- Retaining the copyright to your article

Submit your next manuscript at $\boldsymbol{\nabla}$ springeropen.com 